\title{
Effect of maternal periodontitis and low birth weight-A case control study
}

\author{
LUISE MARIA SOUZA ${ }^{1}$, SIMONE SEIXAS DA CRUZ ${ }^{2}$, ISAAC SUZART GOMES-FILHO ${ }^{1}$, \\ MAURICIO LIMA BARRETO ${ }^{3}$, JOHELLE SANTANA PASSOS-SOARES ${ }^{1}$, \\ SORAYA CASTRO TRINDADE ${ }^{1}$, ANA CLAUDIA MORAIS GODOY FIGUEIREDO ${ }^{2}$, \\ CLAÚDIA MARIA COÊLHO ALVES ${ }^{4}$, JULITA MARIA FREITAS COELHO ${ }^{1}$ \& \\ MARIA ISABEL PEREIRA VIANNA ${ }^{5}$
}

${ }^{1}$ Department of Periodontics, Feira de Santana State University, Bahia, Brazil, ${ }^{2}$ Health Sciences Center, Federal University of Recôncavo da Bahia, Santo Antônio de Fesus, Bahia, Brazil, ${ }^{3}$ Collective Health Institute, Federal University of Bahia, Salvador, Bahia, Brazil, ${ }^{4}$ Department of Dentistry, Federal University of Maranhão, São Luis, Maranhão, Brazil, and ${ }^{5}$ Department of Preventive Dentistry, Federal University of Bahia, Salvador, Bahia, Brazil

\begin{abstract}
Introduction. Since the 1990s, evidence has been raised that there is an association between maternal periodontal disease and undesirable gestational events, for example low birth weight; this issue is controversial. Objective. To evaluate whether there is an association between maternal periodontitis and low birth weight (LBW). Methods. A case-control study was carried out on 951 mothers that had been cared for by the Brazilian Unified Health System in Petrolina-PE and Juazeiro-BA, Brazil. The case group ( $n=269$ ) consisted of mothers of newborns with birth weight $<2500 \mathrm{~g}$ and a control group $(n=682)$ of mothers of newborns with birth weight $\geq 2500 \mathrm{~g}$. An interview was realized, using a questionnaire as well as a full mouth examination to diagnose the periodontal condition. Women who had at least four teeth with probing depth $\geq 4 \mathrm{~mm}$ and clinical attachment loss $\geq 3 \mathrm{~mm}$, with bleeding on probing at the same site, were diagnosed with periodontitis. The birth weight was obtained through the hospital book record. The main association was evaluated using the multivariate regression model, considering confounders. Results. The frequency of periodontitis was $16.4 \%$ (case group) and $17.4 \%$ (control group). Periodontitis did not show an association with $\mathrm{LBW}\left(\mathrm{OR}_{\text {crude }}=0.92 ; 95 \% \mathrm{CI}=0.63-1.35\right)$, even after adjustment for the following confounders: maternal age, pre-gestational body mass index, number of pre-natal consultations, number of pregnancies, maternal schooling level, smoking habit during pregnancy and hypertension $\left(\mathrm{OR}_{\text {adjusted }}=1.00 ; 95 \% \mathrm{CI}=0.61-1.68\right)$. Conclusion. The findings of this study showed no association between maternal periodontal disease and low birth weight, even after appropriate adjustments for confounding factors.
\end{abstract}

Key Words: Epidemiology, low birth weight, periodontitis

\section{Introduction}

Periodontal disease is an oral inflammation, caused by an infection that exhibits high prevalence and affects mainly individuals in developing countries. This disease, in its various clinical entities, is the second biggest oral health problem worldwide. It is estimated that gingivitis affects $\sim 40-85 \%$ of the adult population around the world and periodontitis $\sim 11 \%[1-4]$.

This oral infection is defined as a multifactorial disease, caused by pathogenic bacteria from dental biofilm that stimulates an exacerbated inflammatory response in the gingival tissue, bone, cementum and periodontal ligament. When the inflammation results in the destruction of tooth supporting tissues, this disease is called periodontitis and the absence of treatment can result in tooth loss, pain and discomfort [5]. Other factors influence the development of periodontal disease such as smoking habit, increased age, genetics, stress, diabetes, unfavorable socioeconomic conditions, poor oral hygiene, among others $[2,3,5-7]$.

Correspondence: Simone Seixas da Cruz, Avenida Getúlio Vargas, 379, Centro, Feira de Santana, Bahia 44025-010, Brazil. Tel: +55 75 3623-0661.

Fax: +55 75 3623-0661. E-mail: simone.seixas1@gmail.com

(Received 28 fanuary 2015; accepted 4 May 2015) 
Recently, some studies have shown that localized infection in periodontal tissues may interfere in the development of certain systemic diseases, demonstrating an association with the onset of kidney disease, ischemic disease, diabetes, respiratory conditions and prematurity and low birth weight $[3,5-7]$.

The World Health Organization (WHO) defines low birth weight as any live birth under $2500 \mathrm{~g}$ and has been recognized as an important determinant of infant mortality, accounting for $60-80 \%$ of deaths in the neonatal period. This condition leads to an increased risk of infections, propensity to growth retardation and neuropsychological deficits that may impact on the living conditions of the adult $[8,9]$.

Low birth weight is associated with unfavorable socioeconomic conditions, inadequate nutrition, twinning, primiparity, smoking habit and alcohol consumption during pregnancy, extremes of age, low body mass index (BMI) before pregnancy and complications during pregnancy, including other factors which contribute to the decrease in infant birth weight $[8,9]$. Despite numerous studies on low weight live births, its determinants are not completely clear. About $20 \%$ of the causes that lead to intrauterine growth retardation are unknown in developing countries [9].

Periodontitis is associated with the colonization of the surfaces of the teeth and the gingival sulcus by gram negative anaerobic bacteria, forming a reservoir of micro-organisms, endotoxin and mediators of inflammation that, upon entering the bloodstream, could lead to a systemic chronic inflammatory state able to affect both gestational period and the weight of the newborn $[10,11]$.

Offenbacher et al. [12] were the first to test the above-mentioned hypothesis in the mid-1990s. They observed a strong association between maternal periodontal disease and low birth weight, even after adjustment for confounders such as smoking and drinking during pregnancy, pre-natal care, age and history of bacteremia. Since then, other researchers have conducted studies on the theme, using observational [13-16] and interventional [17-21] methodologies which corroborated the findings of Offenbacher et al. [12].

It is important to note that periodontal status and low birth weight have common risk factors in their causal chain, which may act as confounders or effect modifiers of the association referred to above [22]. More robust studies on this issue, with strict control for confounding, showed several results. Some studies have shown that periodontitis may affect the weight of newborns [17-21], while others found no association [23-33].

Given the importance of low birth weight in the public health context, the high prevalence of periodontal disease and, given that it is still a controversial issue, the aim of this study was to evaluate whether there is an association between maternal periodontitis and low birth weight.

\section{Materials and methods}

\section{Study design and population}

This is a case-control study with the participation of 951 mothers who sought care from June 2009 to December 2011, at the Hospital Dom Malan Petrolina, PE, Brazil, as well as at the Juazeiro Municipal Maternity and at Pró-Matre Hospital in Juazeiro, BA, Brazil. The study population was composed of women that had been cared for by the Brazilian Unified Health System. The case group consisted of 269 mothers of children with birth weight $<2500 \mathrm{~g}$ and the control group of 682 mothers of newborns with birth weight $\geq 2500$ g.

This study was approved by the Ethics and Research Committee of Feira de Santana State University, number 152/2008 (CAAE 0151.0.059.000-08).

\section{Sample size}

The minimum sample size was estimated at 103 cases and 206 controls, with the use of Epi Info software, assuming a confidence level of $95 \%$, a study power of $80 \%$ and a ratio of $1: 2$ between case and controls. Moreover, the frequency of periodontitis was considered as $18 \%$ and $4.7 \%$, respectively, for the case and control groups, based on records from a previous study [13].

\section{Selection of the sample}

Initially, this study conducted a preliminary selection of the participants of case and control groups from a survey carried out every day, about the information on newborns' weight in the book of records of birth from Don Malan, Juazeiro Maternity and Pro-Matre Hospitals. The records were updated daily.

At the time of selection, all mothers of newborns with birth weight $<2500 \mathrm{~g}$ and who were still in the institution after delivery, were invited to join the case group. The control group, consisting of a random sample of mothers of newborns with birth weight $\geq 2500 \mathrm{~g}$, was also selected employing the same source used for the case group. Participants received the necessary information about the survey and, subsequently, they signed the consent form.

The medical history of the patients was revised and those who had at least one of the following characteristics: (1) systemic change that required antibiotic prophylaxis for dental procedures, (2) periodontal treatment during pregnancy, (3) number of teeth less than four or (4) post-partum hospital stay longer than 7 days, were not included in the study. 


\section{Procedures for data collection}

The data pertaining to the weight of newborns were collected from the birth registry of the participating hospitals. The volunteers were asked to reply to trained interviewers using a structured questionnaire. After the interview, one dentist, who was unaware of the group in which the woman had been allocated, performed a periodontal clinical examination to obtain the oral clinical parameters.

\section{Registration of maternal characteristics}

The identification of data related to the mothers was conducted based on data collected from the mother's gestational accompaniment card, hospital records and through interviews, with the application of a structured questionnaire developed specifically for this research.

\section{Periodontal status assessment}

After the questionnaire, the women were examined by one dentist, who was unaware of the outcome and who had received previous training from a specialist in periodontics. For intra-examiner agreement, the Kappa index $( \pm 1 \mathrm{~mm})$ was 0.80 for probing depth and 0.88 for recession/hyperplasia.

The periodontal status of women in the survey was evaluated using the following clinical parameters: probing depth, bleeding on probing and clinical attachment loss. All teeth were examined in the oral cavity, with the exception of the third molars in six different sites: mesiobuccal, mediobuccal, distobuccal, mesiolingual, mediolingual and distolingual. The probing depth, the distance from the gingival margin to the most apical extent of probe penetration, was performed with a William probe (Hu-Friedy, Chicago, IL, USA). If the gingival margin was located between two probe marks, the entire value of the closest mark was used and, when the gingival margin was in a position equidistant from two marks, the greater was considered [34].

In addition, the presence of bleeding was evaluated at the moment of the probing depth measurement, observing after $20 \mathrm{~s}$ if there was some type of bleeding at the site after the removal of the periodontal probe from the sulcus/pocket.

Women who had at least four teeth with probing depth greater than or equal to $4 \mathrm{~mm}$ and clinical attachment loss of $3 \mathrm{~mm}$ or more, with bleeding on probing at the same site, were diagnosed with periodontitis. Mothers who did not fit this criterion were not considered to have the periodontal infection.

\section{Outcome evaluation}

After delivery, the recorded birth weight was collected from the hospital records of mothers who were admitted to the hospitals considered in the study. Babies weighing $<2500$ g were considered low weight cases. It is worth noting that, in accordance with the Health Care Neonatal Manual protocol of the Health Ministry, in use in the hospitals in which this study took place, the weighing of newborns was performed by a nursing assistant within an hour after childbirth, using a digital scale, before weight loss after delivery occurred.

\section{Data analysis procedures}

Initially, an analysis of the distribution of main exposure (periodontitis) and all co-variables under consideration in this study for both the case and control groups was conducted. In the tabular analysis, the candidates for interaction and confounding for the modeling were selected and, using stratified analysis, the existence of potential effect modification and confounding was investigated for the following co-variables: age, sex, race, marital status, maternal schooling level, family income, current occupation, existing diseases, number of hospitalizations during pregnancy, history of low birth weight and intrauterine death, complications in previous childbirth and puerperal disorders, type and number of births, number of pregnancies, use of medication, pregestational body mass index (BMI), variables related to pre-natal care, examinations realized during pregnancy, immunization schedule, quality of pre-natal care, consumption and frequency of smoking, alcohol and drugs, dental care, type and frequency of cleaning.

The analysis of the study was based on a comparison of the frequency of periodontal disease between the two groups. This comparison was made by estimating the risk ratio, obtained by crude and adjusted odds ratios.

A logistic regression model was used to estimate the effect of the main association, simultaneously adjusting for the co-variables of interest using the backward procedure. The software $\mathrm{R}$, version 12.0, was used for processing and analysis of the data.

\section{Results}

The sample of this study consisted of 951 mothers, 269 women in the case group, comprised of mothers of infants with birth weight $<2500 \mathrm{~g}$, and 682 women in the control group, composed of mothers of infants with birth weight equal to or greater than $2500 \mathrm{~g}$. From the total of women invited to compose the sample, $\sim 3 \%$ refused to participate in the study.

The comparison of the general characteristics of the case and control groups indicates that there is homogeneity between them, except for the following covariables (Table I): primiparity $(p<0.001)$, cesarean delivery $(p=0.006)$, history of LBW $(p=0.004)$, 
Table I. Socio-demographics, obstetric and lifestyle characteristics of the case (mothers of newborns with birth weight $<2500 \mathrm{~g}$ ) and control (mothers of newborns with birth weight $\geq 2500 \mathrm{~g}$ ) groups. Petrolina-PE/Juazeiro-BA, Brazil $(n=951)$.

\begin{tabular}{|c|c|c|c|c|c|}
\hline \multirow[t]{2}{*}{ Characteristics } & \multicolumn{2}{|c|}{ Cases $(n=269)$} & \multicolumn{2}{|c|}{ Controls $(n=682)$} & \multirow[t]{2}{*}{$p$} \\
\hline & $n$ & $\%$ & $n$ & $\%$ & \\
\hline \multicolumn{6}{|l|}{ Maternal schooling level ${ }^{\star}$} \\
\hline$>4$ years & 232 & 86.9 & 585 & 86.2 & \multirow[t]{2}{*}{0.77} \\
\hline $0-4$ years & 35 & 13.1 & 94 & 13.8 & \\
\hline \multicolumn{6}{|l|}{ Family income (in minimum salary) ${ }^{\star}$} \\
\hline$>1$ & 75 & 29.2 & 200 & 29.9 & \multirow[t]{2}{*}{0.84} \\
\hline $0-1$ & 182 & 70.8 & 470 & 70.1 & \\
\hline \multicolumn{6}{|c|}{ Maternal occupation during pregnancy } \\
\hline Paid & 75 & 29.9 & 255 & 40.5 & \multirow[t]{2}{*}{0.003} \\
\hline Housewife/student/unemployed & 176 & 70.1 & 375 & 59.5 & \\
\hline \multicolumn{6}{|l|}{ Internation during pregnancy ${ }^{\star}$} \\
\hline No & 218 & 81.0 & 605 & 89.1 & \multirow[t]{2}{*}{$<0.001$} \\
\hline Yes & 51 & 19.0 & 74 & 10.9 & \\
\hline \multicolumn{6}{|l|}{ Type of delivery ${ }^{\star}$} \\
\hline Vaginal & 176 & 65.7 & 508 & 74.4 & \multirow[t]{2}{*}{0.01} \\
\hline Cesarean & 92 & 34.3 & 174 & 25.5 & \\
\hline \multicolumn{6}{|l|}{ Primiparity ${ }^{\star}$} \\
\hline Yes & 132 & 49.4 & 254 & 37.5 & \multirow[t]{2}{*}{$<0.001$} \\
\hline No & 135 & 50.6 & 423 & 62.5 & \\
\hline \multicolumn{6}{|l|}{ History of low birth weight* } \\
\hline Yes & 34 & 13.4 & 48 & 7.3 & \multirow[t]{2}{*}{0.004} \\
\hline No & 220 & 86.6 & 608 & 92.7 & \\
\hline \multicolumn{6}{|l|}{ Marital status } \\
\hline Married/stable union & 214 & 79.9 & 557 & 81.8 & \multirow[t]{2}{*}{0.49} \\
\hline Single/widow/divorced & 54 & 20.1 & 124 & 18.8 & \\
\hline \multicolumn{6}{|l|}{ Age $(\text { years })^{\star}$} \\
\hline $13-18$ & 76 & 28.4 & 120 & 17.8 & \multirow[t]{3}{*}{$<0.001$} \\
\hline $20-35$ & 176 & 65.7 & 522 & 77.2 & \\
\hline$>35$ & 16 & 6.0 & 34 & 5.0 & \\
\hline \multicolumn{6}{|l|}{ Smoking habit during pregnancy ${ }^{\star}$} \\
\hline Yes & 21 & 8.0 & 36 & 5.4 & \multirow[t]{2}{*}{0.14} \\
\hline No & 241 & 92.0 & 629 & 94.6 & \\
\hline \multicolumn{6}{|l|}{ Race/maternal color ${ }^{\star}$} \\
\hline White/yellow & 46 & 17.3 & 92 & 13.9 & \multirow[t]{2}{*}{0.18} \\
\hline Black & 220 & 82.7 & 572 & 86.1 & \\
\hline
\end{tabular}

* Some observations were lost due to lack of information about the variable.

hospitalizations during pregnancy $(p<0.001)$, maternal occupation $(p=0.003)$ and age $(p<0.001)$.

In accordance with Table II, it can be observed that the women in the case group, compared to the control group, had a higher frequency of pre-natal consultation $<6(60.1 \%$ vs $33.8 \%)$, pre-gestational body mass index $\leq 18.5$ ( $8.9 \%$ vs $2.5 \%)$ and hypertension $(26 \%$ vs $10.5 \%)$. Such differences showed high statistical significance $(p<0.001)$.
By observing co-variables related to oral health behavior (Table III), it was found that the study groups were similar for all aspects investigated, with the exception of visit to the dentist during pregnancy, in which mothers in the case group had lower frequency compared to the control group $(p=0.038)$. That is, visiting the dentist during pregnancy was found to be a protective factor against low birth weight. 
Table II. Characteristics related to pre-natal care of the case (mothers of newborns with birth weight $<2500 \mathrm{~g}$ ) and control (mothers of newborns with birth weight $\geq 2500 \mathrm{~g})$ groups. Petrolina-PE/Juazeiro-BA, Brazil $(n=951)$.

\begin{tabular}{|c|c|c|c|c|c|}
\hline \multirow[t]{2}{*}{ Characteristics } & \multicolumn{2}{|c|}{ Cases $(n=269)$} & \multicolumn{2}{|c|}{ Controls $(n=682)$} & \multirow[t]{2}{*}{$p$} \\
\hline & $n$ & $\%$ & $n$ & $\%$ & \\
\hline \multicolumn{6}{|c|}{ Realization of pre-natal care ${ }^{\star}$} \\
\hline Yes & 261 & 97.8 & 671 & 98.5 & \multirow[t]{2}{*}{0.40} \\
\hline No & 6 & 2.2 & 10 & 1.5 & \\
\hline \multicolumn{6}{|c|}{ Number of pre-natal consultations ${ }^{\star}$} \\
\hline$\geq 6$ & 91 & 39.9 & 407 & 66.2 & \multirow[t]{2}{*}{$<0.001$} \\
\hline$<6$ & 137 & 60.1 & 208 & 33.8 & \\
\hline \multicolumn{6}{|c|}{ Urinary infection ${ }^{\star}$} \\
\hline Yes & 109 & 42.6 & 282 & 42.2 & \multirow[t]{2}{*}{0.82} \\
\hline No & 147 & 57.4 & 388 & 57.8 & \\
\hline \multicolumn{6}{|l|}{ Hypertension $\star$} \\
\hline Yes & 67 & 26.0 & 71 & 10.5 & \multirow[t]{2}{*}{$<0.001$} \\
\hline No & 191 & 74.0 & 602 & 89.5 & \\
\hline \multicolumn{6}{|l|}{ Diabetes ${ }^{\star}$} \\
\hline Yes & 9 & 3.5 & 12 & 1.8 & \multirow[t]{2}{*}{0.25} \\
\hline No & 251 & 96.5 & 659 & 98.1 & \\
\hline \multicolumn{6}{|l|}{ Other diseases ${ }^{\star}$} \\
\hline Yes & 19 & 8.1 & 48 & 7.7 & \multirow[t]{2}{*}{0.87} \\
\hline No & 217 & 91.9 & 574 & 92.3 & \\
\hline \multicolumn{6}{|c|}{ Pre-gestational $\mathrm{BMI}^{\star}$} \\
\hline$>18.5 \mathrm{~kg} / \mathrm{m}^{2}$ & 173 & 91.1 & 511 & 97.5 & \multirow[t]{2}{*}{$<0.001$} \\
\hline$\leq 18.5 \mathrm{~kg} / \mathrm{m}^{2}$ & 17 & 8.9 & 13 & 2.5 & \\
\hline \multicolumn{6}{|c|}{ Educational activity during pre-natal care ${ }^{\star}$} \\
\hline Yes & 50 & 20.6 & 159 & 25.5 & \multirow[t]{2}{*}{0.13} \\
\hline No & 193 & 79.4 & 465 & 74.5 & \\
\hline
\end{tabular}

* Some observations were lost due to lack of information about the variable.

Table III. Characteristics related to maternal oral hygiene during the pregnancy of the case (mothers of newborns with birth weight $<2500 \mathrm{~g}$ ) and control (mothers of newborns with birth weight $\geq 2500$ g) groups. Petrolina-PE/Juazeiro-BA, Brazil $(n=951)$.

\begin{tabular}{|c|c|c|c|c|c|}
\hline \multirow[t]{2}{*}{ Characteristics } & \multicolumn{2}{|c|}{ Cases $(n=269)$} & \multicolumn{2}{|c|}{ Controls $(n=682)$} & \multirow[t]{2}{*}{$p$} \\
\hline & $n$ & $\%$ & $n$ & $\%$ & \\
\hline \multicolumn{6}{|c|}{ Tooth brushing after the meal ${ }^{\star}$} \\
\hline Yes & 263 & 97.8 & 662 & 97.2 & 0.63 \\
\hline No & 6 & 2.2 & 19 & 2.8 & \\
\hline \multicolumn{6}{|c|}{ Frequency of brushing ${ }^{\star}$} \\
\hline$\geq 3$ & 97 & 36.1 & 435 & 64.0 & 0.99 \\
\hline$<3$ & 172 & 63.9 & 245 & 36.0 & \\
\hline \multicolumn{6}{|c|}{ Use of dental floss* } \\
\hline Yes & 89 & 33.2 & 245 & 36.2 & 0.38 \\
\hline No & 179 & 66.8 & 431 & 63.8 & \\
\hline \multicolumn{6}{|c|}{ Visit to the dentist* ${ }^{\star}$} \\
\hline Yes & 58 & 22.1 & 191 & 28.7 & 0.04 \\
\hline No & 205 & 77.9 & 474 & 71.3 & \\
\hline
\end{tabular}

* Some observations were lost due to lack of information about the variable. 
Table IV. Periodontal clinical parameters of the case (mothers of newborns with birth weight $<2500 \mathrm{~g}$ ) and control (mothers of newborns with birth weight $\geq 2500$ g) groups. Petrolina-PE/ Juazeiro-BA, Brazil ( $n=951)$.

\begin{tabular}{lll}
\hline Periodontal clinical parameters & $\begin{array}{l}\text { Cases } \\
(n=269)\end{array}$ & $\begin{array}{l}\text { Controls } \\
(n=682)\end{array}$ \\
\hline $\begin{array}{l}\text { Bleeding on probing index (\%) } \\
\text { Mean }\end{array}$ & 10.8 & 8.6 \\
Median & 6.0 & 5.0 \\
Range & $0-92.0$ & $0-68.0$ \\
Probing depth (mm) & & \\
Mean & 1.60 & 1.60 \\
Median & 1.52 & 1.55 \\
Range & $0.34-3.04$ & $0.06-5.5$ \\
Clinical attachment loss (mm) & & 1.60 \\
Mean & 1.59 & 1.55 \\
Median & 1.47 & $0.06-5.5$ \\
Range & $0.69-4.3$ & \\
\hline
\end{tabular}

Table IV shows the following periodontal clinical parameters among cases and controls: bleeding on probing index, probing depth and clinical attachment loss. They were almost similar between the groups.

The proportion of periodontal disease in the case group was approximately the same as found in the control group and the differences were irrelevant, statistically $(16.4 \%$ vs $17.4 \%, p=0.68)$. The crude association analysis (Table V) showed that, among women with periodontal infection, the chance of having children with low birth weight was $8 \%$ lower than that observed among mothers without such disease (ORcrude $=0.92,95 \% \mathrm{CI}=0.63-1.35$ ). This finding was not statistically significant.

In the stratified analysis using Mantel-Henzel method, assuming a relative difference of at most $10 \%$ between crude and adjusted ORs, the following co-variables presented as potential confounders of the association under study: pre-gestational body mass index, number of pre-natal consultations and hypertension. However, even at this stage of the analysis, potential modifier effects were not identified.
After multivariate non-conditional logistic regression analysis, there was no confirmation of confounding. However, the following co-variables were included in the final mathematical model, because they are recognized as classical confounders of the studied association: maternal age, smoking during pregnancy, pre-gestational body mass index, number of pregnancies, hypertension, number of pre-natal consultations and maternal schooling level. The adjusted model also showed no association between maternal periodontal disease and low birth weight (ORadjusted $=1.00,95 \%$ $\mathrm{CI}=0.57-1.69$ ).

\section{Discussion}

The findings of this study showed no association between maternal periodontal disease and low birth weight, even after appropriate adjustments for confounding factors such as maternal age, smoking during pregnancy, pre-gestational body mass index, number of pregnancies, hypertension, number of pre-natal consultations and maternal schooling level (ORcrude $=0.92$, $95 \%$ CI $=0.63-1.35 ;$ ORadjusted $=1.00,95 \%$ $\mathrm{CI}=0.61-1.68)$.

Despite not having verified an association between periodontal infection and low birth weight, visit to the dentist during pregnancy showed a protective effect for the referred outcome. This variable, most probably, functioned as a proxy factor for access to the health service and health behavior co-variables.

The frequency of periodontitis in the control group $(17.4 \%)$ was slightly higher compared to the cases $(16.4 \%)$. However, no significant differences were detected. Similar results were found in studies by Vettore et al. [26] and Buduneli et al. [32], in which the mothers of children with normal weight had a higher prevalence of periodontal disease, when compared to mothers of newborns with low birth weight. In contrast, Bassani et al. [24] detected higher frequency of periodontitis cases compared to the control group. However, these findings do not indicate the statistical significance of the association, consistent with other previous studies [25-32].

However, there are several case-control studies that defend the existence of the referred association

Table V. Odds ratio (OR) and confidence interval (CI) of the association between maternal periodontitis and low birth weight. Petrolina-PE/ Juazeiro-BA, Brazil $(n=951)$.

\begin{tabular}{|c|c|c|c|c|c|c|c|c|}
\hline \multirow[t]{2}{*}{ Maternal periodontitis } & \multicolumn{2}{|c|}{ Cases $(n=269)$} & \multicolumn{2}{|c|}{$\begin{array}{l}\text { Controls } \\
(n=682)\end{array}$} & \multicolumn{2}{|c|}{ Crude analysis } & \multicolumn{2}{|c|}{ Adjusted analysis $^{a}$} \\
\hline & $n$ & $\%$ & $n$ & $\%$ & OR & $95 \% \mathrm{CI}$ & OR & $95 \% \mathrm{CI}$ \\
\hline Yes & 44 & 16.4 & 119 & 17.4 & 0.92 & $0.63-1.35$ & 1.00 & $0.61-1.68$ \\
\hline No & 225 & 83.6 & 563 & 82.6 & & & & \\
\hline
\end{tabular}

${ }^{a}$ Adjustment for: maternal age, smoking during pregnancy, pre-gestational body mass index, number of pregnancies, hypertension, number of pre-natal consultations and maternal schooling level. 
contradicting the results obtained in the present study. Among these studies, there are those that dealt appropriately with confounders, such as Moliterno et al. [35] $(\mathrm{OR}=3.48,95 \% \mathrm{CI}=1.17-10.36)$, Cruz et al. [14] $(\mathrm{OR}=2.30,95 \% \mathrm{CI}=1.14-4.60)$, Siqueira et al. [17] $(\mathrm{OR}=1.67,95 \% \mathrm{CI}=1.11-2.56)$ and Khader et al. [16] $(p<0.001)$ that found a statistically significant association between periodontitis and low birth weight. Thus, this variability of findings reinforces a lack of consensus on the hypothesis.

Even among randomized and controlled intervention studies considered the gold standard in search of evidence for causation, there is disagreement about the existence of this association. On one hand, the results of Michalowicz et al. [27], Offenbacher et al. [29], Ebersole et al. [28], Marcones et al. [31] and Oliveira et al. [23] corroborate the findings of this research. On the other hand, the studies of Lopez et al. [21] and Taranum and Faizundin [18] found that periodontal infection is a risk factor for low birth weight.

A possible explanation for the disagreement concerning the studied association is related to different definitions for periodontitis, since, by adopting different criteria for the diagnosis of periodontal disease, the strength of association is changed, as well as its statistical significance $[13,36]$. In this study, a combination of three clinical parameters (pocket depth, attachment loss and bleeding on probing) was used to obtain a robust criteria for determining the existence of exposure, thereby avoiding the inclusion of false-positives.

Taking into consideration the above issues, the findings of this study should be evaluated with caution. First, it should be subject to the limitations of the chosen epidemiologic methodological design. It is known that case-control investigations are subject to selection bias in the control group, as well as recall bias because of its retrospective nature, compared to cohort and intervention studies.

However, since there is a small number of randomized clinical trials able to give a categorical answer on this theme, an increase in the number of observational studies is contributing to a better understanding of this subject. It is important to note that this study was planned according to the recommendations of STROBE [37], a guide for observational studies in the epidemiology area.

Furthermore, to ensure greater credibility, certain methodological safeguards have been adopted in this study, such as robust exposure and outcome measurements, standardization of the examiner and adjustment procedures in the phase of data analysis.

The criterion for low birth weight was the same as used by the World Health Organization [8], obtained through hospital records. Regarding the diagnosis of periodontal disease, we adopted a robust criterion, with good specificity [13]. From a methodological point of view, the sample size was much higher than the original estimated and the final model was adjusted for potential confounders of the association, thereby giving greater reliability to the results.

Despite the limitations of this investigation, and this is still a controversial topic in the literature, the results can contribute to the body of evidence in question. Although we have not found an association between maternal periodontal disease and low birth weight, we must stress also the need for large studies with methodological rigor, which take into account the inflammatory response of individuals to this oral infection, besides the need for a consensus around the clinical measure of exposure to obtain a better comparison between investigations, giving greater consistency to the theme.

\section{Conclusion}

The findings of the present study, in accordance with the employed method and the limitations, did not verify the association between maternal periodontitis and low birth weight.

Declaration of interest: The authors report no conflicts of interest. The authors alone are responsible for the content and writing of the paper.

\section{References}

[1] Petersen PE, Ogawa H. Strengthening the prevention of periodontal disease: The WHO Approach. J Periodontol 2005;76:2187-93.

[2] Albadar JM. Epidemiology and risk factors of periodontal diseases. Dent Clin North Am 2005;49:517-32.

[3] Scannanpieco FA. Systemic effects of periodontal diseases. Dent Clin North Am 2005;49:533-50.

[4] Kassebaum NJ, Jasrasaria R, Naghavi M, Wulf SK, Johns N, Lozano R, et al. A systematic analysis of global anemia burden from 1990 to 2010. Blood 2014;123:615-24.

[5] Pihlstrom BL, Michalowicz BS, Johson NW. Periodontal disease. Lancet 2005;366:1809-20.

[6] Petricca G, Leppilampi M, Jiang G, Owen GR, Wiebe C, $\mathrm{Tu} \mathrm{Y}$, et al. Localization and potential function of kindlin-1 in periodontal tissues. Eur J Oral Sci 2009;117:518-27.

[7] Cruz SS, Costa Mda C, Gomes-Filho IS, Barreto ML, dos Santos CA, Martins AG, et al. Periodontal therapy for pregnant women and cases of low birthweight: An intervention study. Pediatr Int 2010;52:57-64.

[8] World Health Organization. Optima feeding of low-birthwheight infants: Tecnal review. Genebra: WHO; 2006. Available from http://whqlibdoc.who.int/publications/2006/978924 1595094_eng.pdf.

[9] World Health Organization. Meeting of advisory group on maternal nutrition and low birthweight. Genebra: WHO; 2002. cited 2010 Set 21 Available from http://www.who.int/ nutrition/topics/lbw_strategy_background.pdf.

[10] Offenbacher S, Lin D, Strauss R, McKaig R, Irving J, Barros SP, etal. Effects of periodontal therapy during pregnancy on periodontal status, biologic parameters, and pregnancy outcomes: A pilot study. J Periodontol 2006;77:2011-24. 
[11] Horton AL, Boggess KA, Moss KL, Beck J, Offenbacher S. Maternal periodontal disease and soluble fms-like tyrosine kinase-1 expression. J Periodontol 2009;80:1506-10.

[12] Offenbacher S, Katz V, Fertik G, Collins J, Boyd D, Maynor G, et al. Periodontal infection as a possible risk factor for preterm low birth weight. J Periodontol 1996;67: 1103-13.

[13] Gomes-Filho IS, Cruz SS, Rezende EJ, Dos Santos CA, Soledade KR, Magalhães MA, et al. Exposure measurement in the association between periodontal disease and prematurity/low birth weight. J Clin Periodontol 2007;34: 957-63.

[14] Cruz SS, Costa Mda C, Gomes-Filho IS, Rezende EJ, Barreto ML, Dos Santos CA, et al. Contribution of periodontal disease in pregnant women as a risk factor for low birth weight. Community Dent Oral Epidemiol 2009;37:527-33.

[15] Cruz SS, Costa Mda C, Gomes Filho IS, Vianna MI, Santos CT. [Maternal periodontal disease as a factor associated with low birth weight]. Rev Saude Publica 2005;39:782-7.

[16] Khader Y, Al-shishani L, Obeidat B, Khassawneh M, Burgan S, Amarin ZO, et al. Maternal periodontal status and preterm low birth weight delivery: A case-control study. Arch Gynecol Obstet 2009;279:165-9.

[17] Siqueira FM, Cota LO, Costa JE, Haddad JP, Lana AM, Costa FO. Intrauterine growth restriction, low birth weight, and preterm birth: Adverse pregnancy outcomes and their association with maternal periodontitis. J Periodontol 2007; 78:2266-76.

[18] Tarannum F, Faizuddin M. Effect of periodontal therapy on pregnancy outcome in women affected by periodontitis. J Periodontol 2007;78:2095-103.

[19] Radnai M, Pál A, Novák T, Urbán E, Eller J, Gorzó I. Benefits of periodontal therapy when preterm birth threatens. J Dent Res 2009;88:280-4.

[20] Gomes-Filho IS, Cruz SS, Costa Mda C, Passos JS, Cerqueira EM, Sampaio FP, et al. Periodontal therapy and low birth weight: Preliminary results from an alternative methodologic strategy. J Periodontol 2010;81:1725-33.

[21] López NJ, Smith PC, Gutierrez J. Periodontal therapy may reduce the risk of preterm low birth weight in women with periodontal disease: A randomized controlled trial. J Periodontol 2002;73:911-24.

[22] Wimmer G, Pihlstrom BL. A critical assessment of adverse pregnancy outcome and periodontal disease. J Clin Periodontol 2008;35:380-97.

[23] Oliveira AM, de Oliveira PA, Cota LO, Magalhães CS, Moreira AN, CostaFO. Periodontal therapy and risk for adverse pregnancy outcomes. Clin Oral Investig 2011;15:609-15.

[24] Bassani DG, Olinto MT, Kreiger N. Periodontal disease and perinatal outcomes: A case-control study. J Clin Periodontol 2007;34:31-9.
[25] Vettore MV, Leão AT, Leal Mdo C, Feres M, Sheiham A. The relationship between periodontal disease and preterm low birthweight: Clinical and microbiological results. J Periodontal Res 2008;43:615-26.

[26] Vettore MV, Leal M, Leão AT, da Silva AM, Lamarca GA, Sheiham A. The relationship between periodontitis and preterm low birthweight. J Dent Res 2008;87:73-8.

[27] Michalowicz BS, Hodges JS, DiAngelis AJ, Lupo VR, Novak MJ, Ferguson JE, et al. Treatment of periodontal disease and the risk of preterm birth. N Engl J Med 2006; 355:1885-94.

[28] Ebersole JL, Novak MJ, Michalowicz BS, Hodges JS, Steffen MJ, Ferguson JE, et al. Systemic immune responses in pregnancy and periodontitis: Relationship to pregnancy outcomes in the Obstetrics and Periodontal Therapy (OPT) study. J Periodontol 2009;80:953-60.

[29] Offenbacher S, Beck JD, Jared HL, Mauriello SM, Mendoza LC, Couper DJ, et al. Effects of periodontal therapy on rate of preterm delivery: A randomized controlled trial. Obstet Gynecol 2009;114:551-9.

[30] Michalowicz BS, Hodges JS, Novak MJ, Buchanan W, DiAngelis AJ, Papapanou PN, et al. Change in periodontitis during pregnancy and the risk of pre-term birth and low birthweight. J Clin Periodontol 2009;36:308-14.

[31] Macones GA, Parry S, Nelson DB, Strauss JF, Ludmir J, Cohen AW, et al. Treatment of localized periodontal disease in pregnancy does not reduce the occurrence of preterm birth: Results from the Periodontal Infections and Prematurity Study (PIPS). Am J Obstet Gynecol 2010;202:147.e1-8.

[32] Budunele N, Baylas H, Budunele E, Türkoglu O, Köse T, Dahlen G. Periodontal infections and preterm low weight: A case-control study. J Clin Periodontol 2005;32:174-81.

[33] Moore S, Ide M, Coward PY, Randhawa M, Borkowska E, Baylis $\mathrm{R}$, et al. A prospective study to investigate the relationship between periodontal disease and adverse pregnancy outcome. Br Dent J 2004;197:251-8; discussion 47.

[34] Pihlstrom BL, Ortiz-Campos C, McHugh RB. A randomized four-years study of periodontal therapy. J Periodontol 1981; 52:227-42.

[35] Moliterno LF, Monteiro B, Figueredo CM, Fischer RG. Association between periodontitis and low birth weight: A case-control study. J Clin Periodontol 2005;32:886-90.

[36] Manau C, Echeverria A, Agueda A, Guerrero A, Echeverria JJ. Periodontal disease definition may determine the association between periodontitis and pregnancy outcomes. J Clin Periodontol 2008;35:385-97.

[37] von Elm E, Altman DG, Egger M, Pocock SJ, Gøtzsche PC, Vandenbroucke JP, et al. Strengthening the Reporting of Observational Studies in Epidemiology (STROBE) statement: Guidelines for reporting observational studies. BMJ 2007;335:806-8. 
Copyright of Acta Odontologica Scandinavica is the property of Taylor \& Francis Ltd and its content may not be copied or emailed to multiple sites or posted to a listserv without the copyright holder's express written permission. However, users may print, download, or email articles for individual use. 